\title{
無細胞液体培地でのらい菌の活性維持に 必要な接種菌量
}

\author{
中 村 昌 弘* \\ 古賀病院附属医学研究所 \\ 〔受付：1995年 2 月10日，受理1995年 6 月26日〕 \\ キーワード：らい菌活性維持 \\ 接種菌量 \\ 無細胞培地内らい菌
}

先に, ATP量にして3,000pg以上のらい菌をpH7の仔ウシ血清加リン酸buffer $(\mathrm{M} / 20)$, またはグ リセリン・仔ウシ血清加リン酸buffer $(\mathrm{M} / 20)$ に接種すると， $30^{\circ} \mathrm{C}$ のincubationで，その活性が 4 週間維持されることを報告した。

本報では, 接種菌の活性が3,000pg ATP以上のものと以下のものとについて, 4 週間後のATP 活性を測定した結果，一定の接種菌量がらい菌活性維持に必須であることが確認された。

\section{はじめに}

らい菌が発見されて約 120 年になる今も再現性 のあるらい菌の試験管内増殖は未だ達成されてい ない。ネズミらい菌はらい菌培養実験の一時的モ デル (interim model) として長年試用されたが, 1969年，小川 ${ }^{(1)} に よ り$ 固形培地で，1972年，中村(2) により液体培地で，それぞれ独立にその増菌が達 成された。

この達成のための最も決定的な条件は培地の $\mathrm{pH} 6.0$ 乃至 6.2 に調整することであり,この $\mathrm{pH}$ 之保たれれば,他の培地成分に影響は受ける が，ネズミらい菌の初期増殖はともかく開始され るのである。

従って，らい菌培養研究の基礎データーとして 培地の至適 $\mathrm{pH}$ 決定することは何ものにもまし て必要欠ぐべからざる条件である。このために著

*Corresponding author:

T830 久留米市天神町 120 古賀病院附属医学研究所

Tel: 0942-39-6992 FAX: 0942-39-5763
者は極めて簡単な組成の液体培地を種々な $\mathrm{pH}$ 調整し，それにらい菌を接種し，ATPを指標とし てらい菌の活性がどれくらい期間維持できるかを 検討した。その結果, らい菌活性はpH7の培地で約 4 週間維持されることを見出した ${ }^{(3)}$ 。

しかし,その際, 接種菌量, 換言すれば接種ATP 量が実験結果に大きく影響することに気付いた。 そこで，らい菌接種菌量とその活性維持期間の関 係を改めて整理したので，ここに報告する次第で ある。

\section{材料と方法}

らい菌：国立多摩研究所 松岡正典博士の好意 により分与を受けたタイー53株 ${ }^{(4)}$ を用いた。菌液 の作成法はすでに報告した $0.05 \%$ トリプシン処理

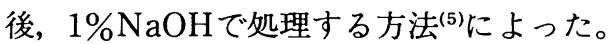
他の供試菌株：M.smegmatis ATCC 14468株は 島根医科大学細菌学教室より分与を受け継代中の もの，E.coliは当病院で分離して継代保存中のも 
のを用いた。

菌数計算：らい菌についてはShepard \& Mc

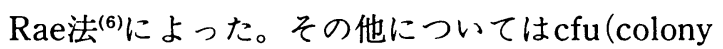
forming units) /mlによった。

培養液：

1）仔ウシ血清加リン酸 buffer (BS):pH7.0の滅 菌リン酸buffer $(\mathrm{M} / 20)$ に $10 \%$ 割りに仔ウシ血 清を加えたもの。

2）グリセリン・仔ウシ血清加リン酸buffer (BGS): 上記リン酸bufferに $2 \%$ の割合にグリセリ ンを加え滅菌，滅菌後，仔ウシ血清を $10 \%$ の割り に加える。

らい菌接種法：培養液に一定量のらい菌菌液を接 種，よく㨨找し， $5.5 \mathrm{ml}$ 当て分注，（スクリュウキ ヤプ付き試験管 $10 \times 12 \mathrm{~mm}), 30^{\circ} \mathrm{C}$ でincubateする。 培養らい菌よりのATP抽出法：培養試験管を 3,000rpm, 20分間遠心, 約 $1 \mathrm{ml}$ を残すよう上清を 除く。残した培養液で沈渣をよく浮遊させ, Eppendorf tubeに移し，13,000rpm，6分間遠心， 上清を捨て, 沈渣を得る。

以降の操作は既報(7)のATP抽出法を用いた。

\section{実験結果}

得られた実験結果は表 1 に示した。接種時の $\mathrm{ATP}$ 量が $3,000 \mathrm{pg}$ 以上の場合, $30^{\circ} \mathrm{C}$ ，で 4 週間 incubateした後のらい菌のATP量は大幅に増加 するか, 接種時の值にほぼ近い程度に維持された。

これに対して，1例の例外はあるが，接種時の ATP量が3,000pg以下の場合は, $30^{\circ} \mathrm{C}$ で 4 週間, incubateした後のらい菌の活性維持は極めて悪 く，ほとんどが20\%以下であった。

次に,ATP量と菌数との関係, 換言すれば, ATP定量の検量線に相当する知見を得るために， らい菌，M.smegmatis，およびE.coliを用いて， 菌液を 2 段階希釈し，それらの材料についてATP 量を測定した。

得られた結果は表 2 に示した。

表に見る如く，菌液の 2 段階希釈に従って，正 確な減少ではないが,一応の半減傾向が見られた。 またこの結果によればATPで測定できる限界は 極めて限られた範囲であり，らい菌ではharvestさ れた時点の活性にも依存するが, $10^{6}-10^{7}, M$.
Table 1 Inoculum sizes necessary for maintaining the activity of Mycobacterium leprae in cell-free liquid media

\begin{tabular}{l|l|ll}
\hline Expt.No. & $\begin{array}{l}\text { ATP of the } \\
\text { initial inoculum }\end{array}$ & \multicolumn{2}{|c}{$\begin{array}{l}\text { ATP of incubated cells for 4 } \\
\text { weeks' incubation at } 30^{\circ} c^{*}\end{array}$} \\
\hline 122 & $21.0 \mathrm{ng}$ & $27.0 \mathrm{ng}$ & $(128.6 \%)^{* *}$ \\
128 & 17.4 & 21.0 & $(120.7 \%)$ \\
$128 \mathrm{G} \#$ & 15.6 & 27.0 & $(173.1 \%)$ \\
115 & 11.4 & 18.0 & $(157.9 \%)$ \\
$129 \mathrm{G}$ & 11.4 & 10.5 & $(92.1 \%)$ \\
$143 \mathrm{G}$ & 8.85 & 14.1 & $(159.3 \%)$ \\
109 & 8.7 & 13.5 & $(155.2 \%)$ \\
127 & 7.5 & 6.6 & $(88.0 \%)$ \\
$141 \mathrm{G}$ & 6.9 & 8.25 & $(119.6 \%)$ \\
138 & 3.84 & 3.9 & $(101.6 \%)$ \\
$139 \mathrm{G}$ & 3.15 & 2.94 & $(93.3 \%)$ \\
\hline 118 & 3.0 & 0.75 & $(22.7 \%)$ \\
$131 \mathrm{G}$ & 2.55 & $<0.1$ & \\
$125 \mathrm{G}$ & 2.4 & 1.02 & $(42.5 \%)$ \\
$150 \mathrm{G}$ & 1.98 & 0.42 & $(21.2 \%)$ \\
$132 \mathrm{G}$ & 1.74 & $<0.1$ & \\
$133 \mathrm{G}$ & 1.44 & 0.33 & $(22.9 \%)$ \\
141 & 1.44 & 1.2 & $(83.3 \%)$ \\
\hline
\end{tabular}

* per tube

** ng

*** percent of the ATP of an initial inoculum (at zero-time) Medium: $\mathrm{M} / 20$ phosphate buffer $(\mathrm{pH} 7)+10 \%$ fetal calf serum \# : Medium $+2 \%$ glycerin $(\mathrm{v} / \mathrm{v})$

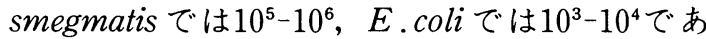
る。それより少ない菌量のATPは測定できない。 また,この結果からE . coliは均等な菌液であるこ と，抗酸菌，殊にらい菌は短時間に自然凝集を起 こしていることを示している。

Table 2 Relationship between dilution of the materials and ATP values extracted from the diluted corresponding materials

\begin{tabular}{c|c|c|c|c}
\hline Materials & \multicolumn{2}{|c|}{$M$. leprae } & $\begin{array}{c}\text { M.smeg- } \\
\text { matis }\end{array}$ & E.coli \\
\hline $\begin{array}{c}\text { Number of } \\
\text { cells/ml }\end{array}$ & $21 \times 10^{9}$ & $49.5 \times 10^{8}$ & $1 \times 10^{7}$ & $1 \times 10^{5}$ \\
\hline Dilution : & & & & \\
$1: 2$ & $42.0^{*}(100 \%)$ & $72.0(100 \%)$ & $\mathrm{NT}^{* *}$ & $\mathrm{NT}$ \\
$1: 4$ & $27.6(65.7)$ & $36.0(50.0)$ & $146.7(100 \%)$ & $57.0(100 \%)$ \\
$1: 8$ & $13.2(31.4)$ & $13.8(19.2)$ & $54.0(36.8)$ & $33.0(57.9)$ \\
$1: 16$ & $6.0(14.3)$ & $7.8(10.8)$ & $30.0(20.4)$ & $48.6(32.6)$ \\
$1: 32$ & $3.0(7.1)$ & $4.8(6.7)$ & $5.4(3.7)$ & $9.3(16.3)$ \\
$1: 64$ & $1.5(3.6)$ & $2.1(2.9)$ & $\mathrm{NT}$ & $\mathrm{NT}$ \\
$1: 128$ & $<0.1$ & $<0.1$ & $\mathrm{NT}$ & $\mathrm{NT}$ \\
\hline
\end{tabular}

*ng ** NT: not tested

次に, 同一菌量を12本の培養試験管に分注して, $30^{\circ} \mathrm{C} ， 24$ 時間培養後，集菌し，それよりATPを抽 
出し, ATP量のバラつきを測定した。実験は 2 回, 試料を別にして行った。その結果は表 3 に示した とおりである。

この結果は同一菌量を接種したにも拘らず，変 動係数 (Coeffecient of Variation) は13.0615.05を示した。

Table 3 ATP value deviations among tubes of the medium containing the same concentration of cells of $M$. leprae incubated for 24 hours at $30^{\circ} \mathrm{C}$

\begin{tabular}{c|c|c}
\hline Tube lot & Sample 1 & Sample 2 \\
\hline 1 & $43.5 \mathrm{ng}$ & $42.0 \mathrm{ng}$ \\
2 & 42.0 & 39.0 \\
3 & 40.5 & 37.5 \\
4 & 39.0 & 37.5 \\
5 & 39.0 & 33.0 \\
6 & 36.0 & 31.8 \\
7 & 36.0 & 31.5 \\
8 & 33.0 & 31.5 \\
9 & 31.5 & 30.0 \\
10 & 31.5 & 30.0 \\
11 & 30.0 & 26.7 \\
12 & 24.6 & 33.38 \\
\hline Mean & 35.55 & 4.36 \\
\hline SD & 5.35 & 13.06 \\
\hline CV(\%) & 15.05 & \\
\hline
\end{tabular}

Inoculum size: One tenth $\mathrm{ml}$ of $M$. leprae suspension containing cells of $27.8 \times 10^{7} / \mathrm{m} \ell$.

Medium: $5.5 \mathrm{ml}$ of $10 \%$ fetal calf serum- M/20 phosphate buffer(pH 7) per $90 \mathrm{~mm} \times 12 \mathrm{~mm}$ screw-cap tube.

ATP was extracted from centrifuged sediment and measured by the procedure of the firefly biolumines cent technique.

SD: Standard deviation.

$\mathrm{CV}(\%)$ : Coefficient of variation.

\section{考察}

らい菌の活性を少しでも長く無細胞培養系で維 持する環境の確立はらい菌培養実験において最も 基礎的条件である。そのために極めて簡単な溶液 を用いて, 活性維持に必要な至適 $\mathrm{pH}$ 検討したと ころ, $\mathrm{pH}$ 7の溶液において, らい菌活性は他のpH に比して，比較的長く維持されることが判明し た(3)。ただしこの際, 接種菌量を考慮しないと,こ のevidenceの再現性が得られないことも明らかに なった。その接種量はATP量で表現すれば, 3,000 pg以上である。なぜ, $3,000 \mathrm{pg}$ 以上のATP量が必 要なのかは現在不明である。これには菌側の条件
と溶液（培地）側の条件が関与していることは明

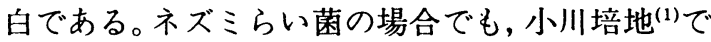
は $10^{9}$ 以上の接種菌量がないとコロニーの発生は 困難であるし，液体培地のNakamura system ${ }^{(2)}$ でも， $10^{5}$ 以上の接種菌量が増菌に必要である。一 般細菌でも inoculumが多いほどコロニ一の発生 は早い。おそらくエネルギーの蓄積量の齊す結果 であろう。これはまた培地の優劣と接種菌の活性 に当然依存している。らい菌の活性をin vitroで 維持するためには培地が優れていれば勿論，長期 間活性は維持されるであろうし，一方，らい菌が 新鮮でin vivoでlog phaseの菌であれば活性維持 期間は長いであろう。従って，この報告で， 3,000 pg以上のATP量が必要だということはあくまで 血清加リン酸Buffer培地またはグリセリン・血清 加リン酸Buffer培地系の条件下での結果である。

接種らい菌の活性を知るには，現在のところ接 種菌量全体としてのATP量を測定する以外に, BACTEC 460 TB System ${ }^{(8)}$ およびEuddemeyer

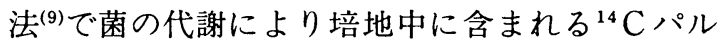
ミチン酸より生ずる ${ }^{14} \mathrm{CO}_{2}$ の測定により可能であ るが，これらは同位元素を使用する関係で限られ た研究室のみでしか行うことができない。その点, ATPを測定する方法はどの研究室でも可能であ る。

ここで, 測定したATP量が菌数に比例している か否かはATP量の価値判断に梁く影響する。も し，菌の活性以外のものが抽出されてATP量に関 与しているならば, 得られたATP量は無意味であ る。そこで, 菌液の希釈度とATP量とを検討した。 その結果, 接種時のらい菌菌液では概ね菌数と ATP量とが比例したが, E.coliの希䣋に比して, 抗酸菌，とくにらい菌は希釈度とATPが正確に平 行しなかった。このことはE.coliは均等菌液の侭 であることを示し, らい菌は急速に自然凝集が起 きていることを示唆している。このことはATP量 測定の信頼度に関係する重要なことなので，次に 同一菌量を多くの試験管に接種して一定時間培養 後のATP量を比較検討した。その結果, ATP収量 に13.06\%から $15.05 \%$ の変動係数が得られた。こ れは菌接種のさい菌液のなかにすでに自然凝集が 起きていて，同一菌量を接種したはずの菌量が実 は同一ではなかったことを示唆している。何故な 
ら，ATPは 1 本の試験管内の菌量をすべて集め て, それより抽出しているからである。しかも, 24時間のincubationであるので, 接種菌液中のら い菌の活性の差は影響しないと思われる。また, ATP測定に至適な菌濃度であるためにここで得 られた測定量は正確である。しかし，この程度の 変動係数はあっても許容範囲のものであり, 培養 実験の結果判定では 2 倍の差はほとんど誤差の範 囲であり, 真に増菌が起きているかの判定は10倍 以上の増菌量が必要だからである。

ここで示した 4 週間incubateしたあとのらい菌 体より抽出されたATP量は確かに活性あるらい 菌菌数を間接的に表現しているということが出来 よう。即ち, 4 週間後のATP量がinoculumのATP 量と同程度, あるいはそれを上回る量であれば, らい菌の活性が維持されていることを示唆してい るし, 減少すれば, らい菌の活性は失われている ことを示唆している。このことから,一定以上の inoculumを用いて, 抽出されたATP量を比較す れば, らい菌活性維持の如何を類推することが出 来る。

\section{謝辞}

この研究を行うに当たりATP測定装置使用の 機会を提供頂いた福岡歯科大学 萩原義郷学長に 深甚なる謝意を捧げる。ままた，研究にご協力下さ った古賀病院附属医学研究所仙頭聖一, 秏田満子 両氏に感謝の意を表する。

\section{文献}

1)小川辰次・本村恵子：鼠らい菌に関する研究,
第 1 報 鼠らい菌培養の試み レプラ $38: 246$ -254 (1969).

2) Nakamura, M.: Multiplication of M. lepraemurium in cell-free medium containing $\alpha$-ketoglutaric acid and cytochrome c. J. Gen. Microbiol., 73: 193-195(1972).

3) Nakamura, M.: Optimal pH for preserving the activity of $M$. leprae during incubation of cells in a cell-free liquid medium. Intl. J. Lepr. 61: 28-34, (1995).

4) Matsuoka, M., Kohsaka, K. and Dayanghirang, J. A.: Characteristics of $M$. leprae Thai - 53 strain. Intl. J. Lepr. 60: 722(1992).

5) 中村昌弘：らい菌接種ヌードマウス足蹠乳剤内 迷入雑菌の除去, 日本らい学会雑誌, 64：4750 (1994).

6) Shepard, C. C, and McRae: A method for counting acid-fast bacteria. Intl. J. Lepr. 36: 78-82, (1968).

7) 中村昌弘：らい菌菌体よりのアデノシン-3リン酸 (ATP) 抽出に及ぼすクロロフォルムの 効果. 日本らい学会雑誌, 63：99-104(1994).

8) Buddemeyer, E., Hutchinson, R. and Cooper, M.: Automatic quantitative radiometer assay of bacterial metabolism. Clin. Chem. 22: 1459-1463(1976).

9) Ramasesh, N., Adams, L. B., Franzblau, S. $\mathrm{G}$.and Krahenbuhl, J. L.: Effects of activated macrophages in Mycobacterium leprae. Infect. Immum. 59: 2864-2869 (1991). 


\title{
Inoculum sizes necessary for maintaining the activity of Mycobacterium leprae in cell-free liquid media
}

\author{
Masahiro Nakamura \\ Koga Hospital Medical Research Institute and \\ Department of Microbiology, Kurume \\ University School of Medicine
}

key words: Maintenance of the activity of M.leprae, Inoculum sizes of $M$. leprae, $M$. leprae in cell-free media

Evidence was presented in the previous paper that the activity of cells of $M y$. cobacterium leprae was maintained in the phosphate buffer( $\mathrm{pH} 7)$ containing fetal calf serum $(10 \%)$ with / without glycerin $(2 \%)$ for approximately 4 weeks during incubation of cells at $30{ }^{\circ} \mathrm{C}$, when the inoculum having more than 3,000 pg ATP was used.

In the present paper, it is confirmed that the definite inoculum sizes are essential for obtaining the reproducible results that are described above, by using the inocula containing more and less than 3,000pg ATP. 